\title{
Pengaruh Pola Asuh Permisif Orangtua Terhadap Kedisiplinan Belajar Anak di Lingkungan Pasar Baru Kelurahan Padang Masiang, Barus Kabupaten Tapanuli Tengah
}

\author{
Sani Susanti, M.Pd \\ Elli Yana Ginting
}

\author{
Pendidikan Luar Sekolah, FIP Unimed
}

\begin{abstract}
Abstrak
Masalah dalam penelitian ini yaitu sikap orangtua yang tidak peduli akan perkembangan anak remajanya sehingga menyebabkan kedisiplinan belajar anak menurun. Tujuan dari penelitian ini yaitu untuk menjelaskan pengauh pola asuh permisif orangtua terhadap kedisiplinan belajar anak di Lingkungan Pasar Bari. Penelitian ini merupakan penelitian bersifat deskriptif kuantitatif. Sampel dalam penelitian ini adalah anak remaja ( 13-15 tahun) beserta dengan orangtua remajanya. Teknik pengumpulan data yang digunakan dalam penelitian ini adalah observasi, wawncara, dan angket. Teknik analiis data yang digunakakan adalah koefisien produk moment dan uji t pada taraf signifikan alpha 0,05. Hasil uji analisis data pada taraf signifikan diperoleh $r_{\text {hitung }}(0,559)>r_{\text {tabel }}(0,312)$. Hasil uji $t$ diperoleh $t_{\text {hitung }}(4,14)>t_{\text {tabel }}(1,68)$. Sesuai dengan penerimaan dan penolakan hipotesis, maka hipotesis kerja $(\mathrm{Ha})$ yang diajukan diterima pada taraf signifikansi 95\%. Berdasarkan hasil analisis data tersebut ternyata dapat dikatakan orangtua di daerah pasar baru menggunakan pola asuh permisif yang mempunyai sifat negatif dimana mereka tidak peduli terhadap perkembangna kedisiplinan belajar anaknya.
\end{abstract}

Kata Kunci : Pola Asuh; Permisif; Disiplin Belajar

PENDAHULUAN

Pendidikan merupakan tanggung jawab bersama, baik pemerintah, keluarga sekolah maupun masyarakat dalam rangka mencapai cita-cita bangsa Indonesia yaitu menciptakan masyarakat adil dan makmur. Pendidikan memegang peranan penting dalam kehidupan manusia, tak satupun keberhasilan manusia di dalam kehidupan ini tercapai melaui proses pendidikan. Proses pendidikan itu sendiri berlangsung di lingkungan keluarga, sekolah dan lingkungan masyarakat.

Orangtua dan guru merupakan pemimpin, dan anak merupakan murid yang belajar dari mereka tentang cara hidup menuju ke kehidupan yang lebih berguna dan bahagia sedangkan disiplin diri merupakan substansi esensial di era globalisasi untuk dimiliki dan dikembangkan oleh anak karena dengan menerapkan disiplin anak dapat memiliki kontrol internal untuk berperilaku yang senantiasa taat moral. Sehingga anak tidak hanyut oleh arus globalisasi, tetapi sebaliknya ia mampu menerapkan konsep disiplin dalam dirinya dan melalui disiplinlah mereka dapat belajar berperilaku dengan cara yang diterima masyarakat. Disiplin merupakan salah satu kebutuhan dasar anak dalam rangka pembentukan dan pengembangan wataknya secara sehat. Tujuannya adalah agar anak dapat secara kreatif dan dinamis mengembangkan hidupnya 
dikemudian hari. Kedisiplinan harus ditanamkan sejak dini kepada anak, apabila tidak ada kedisiplinan maka seorang anak akan mengalami kehidupan yang kurang teratur.

Sebagian orangtua di lingkungan Pasar Baru Kelurahan Padang Masiang Kecamatan Barus Kabhoaten Tapanuli Tengah ada yang tidak peduli dengan kehidupan anak-anaknya, hal ini disebabkan karena kesibukan orangtua (bekerja). Karena kesibukannya dalam mencari nafkah, banyak orang tua yang memberi kebebasan lebih bagi anaknya untuk menjalani hidup anaknya sendiri. Hal ini sering sekali menjadi masalah, terutama berkaitan dengan bagimana perkembangan diri anak dalam disiplin belajar anak. Hal ini mengakibatkan anak tidak menerapkan disiplin dalam proses pembelajaran di sekolahnya. Misalnya, anak datang terlambat ke sekolah atau datang sesuka hatinya, anak tidak menghormati orangtua dan guru, tidak mau belajar pada waktunya, bahkan sering bolos sekolah. Orangtua tipe seperti ini disebut sebagai orangtua yang menerapkan pola asuh permisif dalam mendidik anaknya. Rumusan masalah dalam penelitian ini yaitu "Bagaimana Pengaruh Pola Asuh Orangtua Permisif terhadap Kedisiplinan Belajar Anak di Lingkungan
Pasar Baru Kelurahan Padang Masiang Barus?".

\section{KAJIAN PUSTAKA}

\section{Pola Asuh Permisif Orangtua}

Pola asuh terdiri dari dua kata yaitu pola dan asuh. Dalam Kamus Besar Bahasa Indonesia, pola berarti corak, model, sistem, cara kerja, bentuk (struktur) yang tetap. Sedangkan kata asuh dapat berarti menjaga (merawat dan mendidik) anak kecil, membimbing (membantu; melatih dan sebagainya), dan memimpin (mengepalai dan menyelenggarakan) satu badan atau lembaga.

Gunarsa (2010:54) menjelaskan pola asuh merupakan perlakuan orangtua dalam interaksi yang meliputi orangtua menunjukkan kekuasaan dan cara orangtua memperhatikan keinginan anak. Kekuasaan atau cara yang digunakan orangtua cenderung mengarah pada pola asuh yang diterapkan. Orangtua adalah pendidik utama dan pertama sebelum anak memperoleh pendidikan di sekolah, karena dari keluargalah anak pertama kalinya belajar. Jadi keluarga tidak hanya berfungsi sebagai penerus keturunan saja, tetapi lebih dari itu sebagai pembentuk kepribadian anak. Steinberg (dalam Kusdwiratri, 2011:93) menyimpulkan “ orangtua permisif tidak pernah 
memberikan hukuman dan menerima apa yang dilakukan anak tanpa memberikan intervensi". Orangtua tipe ini memberikan respon pada anak dengan cara menerima apapun tindakan anak.

\section{Kedisiplinan Belajar Anak}

Menurut Tu'u (2004:37) kedisiplinan begitu penting karena beberapa alasan berikut: (1). Dengan kedisiplinan yang muncul karena kesadaran diri anak berhasil dalam belajarnya. (2). Tanpa kedisiplinan yang baik, suasana sekolah dan rumah menjadi kurang kondusif bagi sebagai tempat kegiatan pembelajaran. (3). Kedisiplinan merupakan jalan bagi anak untuk sukses kelak. (4). Kedisiplinan memberi dukungan bagi terciptanya perilaku yang tidak menyimpang.

\section{METODE PENELITIAN}

Metode penelitian yang digunakan penulis dalam penelitian ini adalah metode deskriptif dengan pendekatan kuantitatif. Penelitian kuantitatif dari jenis datanya adalah penelitian yang data penelitiannya bersifat numerik, yaitu yang berhubungan dengan angka-angka. Metode deskriptif merupakan suatu penelitian yang diungkapkan untuk mengamati permasalahan secara sistematis dan akurat mengenai fakta dan sifat objek tertentu.
Populasi dalam penelitian ini adalah seluruh remaja dan orangtua dari remaja yang bertempat tinggal di Lingkungan Pasar Baru Kelurahan Padang Masiang Barus. Banyaknya remaja (yang berusia 13-17 tahun) yang tinggal di daerah tersebut sebanyak 75 orang dan jumlah orangtua remajanya sebanyak 75 orang (berdasarkan Data Statistik penduduk Kelurahan Pasar Baru).

Setelah populasi diketahui dengan jelas, maka peneliti menetapkan besar atau banyak sampel dalam penelitian ini adalah anak remaja dan orangtua dari sebagian jumlah populasi remaja dan orangtua di Lingkungan Pasar Baru, Kelurahan Padang Masiang Barus.

Teknik analisis data yang digunakan dalam penelitian ini adalah teknik analisis data deskriptif kuantitatif. Analisis data kuantitatif merupakan pengujian data yang dinyatakan dalam bilangan dan memerlukan teknik statistika (dalam Kasmadi 2013:91). Teknik analisis data yang digunakan dalam penelitian ini digunakan untuk mengetahui pengaruh "Pola Asuh Orangtua terhadap Kedisiplinan Belajar Anak di Lingkungan Pasar Baru Kelurahan Padang Masiang Barus". 
Untuk menganalisis data yang sudah diperoleh, digunakan rumus korelasi product moment:

$\operatorname{rxy}=\frac{n \sum X Y-\left(\sum X\right)\left(\sum Y\right)}{\left.\sqrt{\left\{n \sum x^{2}-\left(\sum X\right)^{2}\right.}\right\}\left\{n \sum Y^{2}-\left(\sum Y\right)^{2}\right\}}$

Keterangan:

$\mathrm{r}_{\mathrm{xy}}=$ Koefisien korelasi

$\mathrm{X}=$ Nilai untuk total item pola asuh permisif orangtua

$\mathrm{Y}=$ Nilai total item kedisiplinan belajar anak

$\mathrm{n} \quad=$ Jumlah sampel

Untuk menentukan apakah hipotesis yang telah dirumuskan dapat diterima atau tidaknya digunakan uji " $\mathrm{t}$ " dengan rumus:

$$
\mathrm{t}=\frac{r \sqrt{n-2}}{\sqrt{1-r^{2}}}
$$

Dimana:

$\mathrm{r}=$ koefisien korelasi

$\mathrm{n}=$ jumlah sampel

$\mathrm{n}-2=\mathrm{dk}=\mathrm{df}-$ derajat kebebasan $=$ degresi of random dengan membanding harga $r_{\text {tabel }}$ untuk $n$ (jumlah seluruh yang bertugas sesuai sampel) dan taraf signifikannya $95 \%$ atau $\propto=5 \%$.

Penelitian ini dilakukan oleh penulis di daerah Lingkungan Pasar Baru, Kelurahan Padang Masiang Barus Kecamatan Barus, Kabupaten Tapanuli Tengah Waktu penelitian dalam penyusunan skripsi ini dilaksanakan dari bulan Februari sampai dengan Agustus 2015.

\section{HASIL PENELITIAN DAN \\ PEMBAHASAN}

Ringkasan Uji Hipotesis

\begin{tabular}{|c|c|c|c|c|c|}
\hline \multirow{3}{*}{$\begin{array}{l}\text { Korel } \\
\text { asi }\end{array}$} & \multicolumn{2}{|c|}{$\begin{array}{l}\text { Koefisien } \\
\text { Korelasi }\end{array}$} & \multicolumn{2}{|l|}{ Uji t } & \multirow{3}{*}{$\begin{array}{l}\text { Koefisi } \\
\text { en } \\
\text { Determi } \\
\text { nasi }\end{array}$} \\
\hline & \multirow[t]{2}{*}{$r_{\text {hitum }}$} & $r_{\text {tabe }}$ & $t_{\text {hitun }}$ & $t_{t a b e}$ & \\
\hline & & & & & \\
\hline $\begin{array}{l}\mathrm{X} \\
\text { atas } \\
\mathrm{Y}\end{array}$ & 0,559 & $\begin{array}{l}0,31 \\
2\end{array}$ & 4,148 & 1,68 & $31,24 \%$ \\
\hline
\end{tabular}

Dari tabel di atas, menunjukkan terdapat hubungan antara pola asuh permisif orangtua (X) dengan kedisiplinan belajar anak (Y) dibuktikan dari $r_{x y}>r_{\text {tabel }}$ yaitu $0,559>0,312$ dengan koefisien determinasi 31,24\%. Melalui uji $\mathrm{t}$ yang dilakukan ternyata diperoleh $t_{\text {Ditung }}=4,148$ sedangkan nilai $t_{\text {tabel }}=1,68$ karena $t_{\text {hitung }}>t_{\text {tabel }}$ hal ini menunjukkan pola asuh permisif orangtua mempunyai pengaruh negatif nyata terhadap kedisiplinan belajar anak di Lingkungan Pasar Baru Kelurahan Padang Masiang Barus.

Pembahasan 
Berdasarkan hasil yang diperoleh dari langkah-langkah yang ditempuh dalam penelitian ini, maka dapat diperoleh gambaran temuan peneltian yaitu terdapat pengaruh yang bersifat negatif Pola Asuh Permisif Orangtua terhadap Kedisiplinan Belajar Anak Remaja (13 -15) tahun di Lingkungan Pasar Baru Kelurahan Padang Masiang Barus. Dari hasil analisis korelasi ditemukan harga korelasi antara variabel pola asuh permisif orangtua $(\mathrm{X})$ dengan kedisiplinan belajar anak remaja (13 -15 tahun) (Y) sebesar 0,559 dan setelah dikonsultasikan dengan $r_{\text {tabel }}$ pada $\alpha=$ 0,05 adalah 0,312 . Ini berarti $r_{\text {hitung }}>r_{\text {tabel }}$ yaitu $(0,559>0,312)$. Jika $r_{\text {hitung }}$ lebih besar dari $r_{\text {tabel }}$ maka hipotesis diterima. Untuk mengetahui keberartian (signifikansi) dari korelasi ini dilakukan uji t, maka diperoleh thitung 4,148 sedangkan $t_{\text {tabel }} 1,68$ ini berarti $t_{\text {hitung }}>$ $t_{\text {tabel }}$ yaitu $(4,148>1,68)$ yang berarti terdapat pengaruh yang signifikan. Dengan demikian dinyatakan terdapat pengaruh yang bersifat negatif pola asuh permisif orangtua terhadap kedisiplinan belajar anak di Lingkungan Pasar Baru Kelurahan Padang Masiang Barus, yang berarti hipotesis alternatif diterima dan dalam kriteria korelasi termasuk ke dalam korelasi tinggi. Sedangkan dari hasil hasil uji determinasi diperoleh besarnya persentase pola asuh pemisif orangtua adalah sebesar $31,24 \%$.

Tujuan dari penelitian ini adalah untuk mengetahui apakah terdapat pengaruh yang bersifat negatif antara pola asuh permisif orangtua dengan kedisiplinan belajar anak remaja (13 -15 tahun) di Lingkungan Pasar Baru Kelurahan Padang Masiang Barus yang menyebabkan rendahnya tingkat kedisiplinan belajar anak remaja (13-15 tahun). Dari analisis data telah terbukti bahwa terdapat pengaruh yang bersifat negatif antara pola asuh permisif orangtua dengan kedisiplinan belajar anak di Lingkungan Pasar Baru Kelurahan Padang Masiang Barus. Hal ini ditunjukkan dari perolehan nilai perhitungan korelasi product moment $\left(r_{\text {hitung }}=0,559>r_{\text {tabel }}=0,312\right)$. Berdasarkan dari perolehan perhitungan analisis data dapat dikatakan bahwa orangtua di Lingkungan Pasar Baru Barus tidak peduli terhdapa perkembangan anaknya yang meyebabkan kedisiplinan belajar anak menurun.

Faktor yang berpengaruh terhadap kedisiplinan belajar anak adalah dari dalam diri anak tersebut maupun dari luar diri anak tersebut. Faktor dari luar diri anak tersebut dalam meningkatkan 
kedisiplinan belajarnya merupakan faktor sosial yang bersumber dari orangtua yaitu pola asuh orangtua. Hasil penelitian ini sejalan dengan yang dikemukakan oleh Hurlock (dalam Andriani 2010:22) aspekaspek pola asuh permisif orangtua meliputi:

1. Kontrol terhadap anak kurang

Ini menyangkut tidak adanya pengarahan perilaku anak sesuai dengan norma masyarakat. Tidak menaruh perhatian dengan siapa saja anak bergaul.

2. Pengabaian keputusan

Mengenai membiarkan anak untuk memutuskan segala sesuatu sendiri tanpa adanya pertimbangan dengan orangtua.

3. Orangtua bersikap masa bodoh

Menyangkut ketidakpedulian orangtua terhadap anak, tidak adanya hukuman saat anak sedang melakukan tindakan yang melanggar norma.

4. Pendidikan bersifat bebas

Mengenai kebebasan anak uttuk memilih sekolah sesuai dengan keinginan anak, tidak adanya nasehat disaat anak berbuat kesalahan, dan kurang memperhatikan pendidikan moral dan agama.

Berdasarkan aspek-aspek diatas dan dikaitkan dengan perolehan hasil penelitian maka dapat disimpulkan bahwa aspek-aspek pola asuh orangtua permisif adalah kontrol terhadap anak yang sangat longgar, pengabaian keputusan yang dilakukan oleh anak, dan sifat orangtua yang masa bodoh tentang kehidupan anak, serta bersifat bebas mendidik anak. Dalam pola asuh permisif ini dijelaskan bahwa sikap orangtua selalu menerima implus, keinginan dan perbuatan anaknya, serta cenderung kurang memonitor perilaku anaknya. Meskipun anaknya cenderung ramah dan mudah bergaul, tetapi mereka kurang memiliki pengetahuan tentang perilaku yang tepat untuk situasi sosial pada umumnya dan kurang bertanggung jawab atas perilakunya yang salah.

Orangtua dengan gaya asuh permisif ini menerapkan relatif sedikitnya tuntutan kepada anaknya dan cenderung inkosisten dalam menerapkan disiplin pada anaknya. Akibatnya, anak cenderung kurang menerapkan sikap kedisiplinan dalam belajar maupun kehidupan sosialnya.Lingkungn keluarga memiliki peranan yang sangat penting dalam upaya mengembangkan pribadi anak.

Orangtua adalah salah satu model utama dan tokoh teladan anak dalam proses perkembangannya. Pola asuh memiliki pengaruh yang tinggi terhadap kedisiplinan belajar anak. Dalam hal ini 
semakin baik pola asuh orangtua dalam mendidik anak maka akan semakin baik pula kedisiplinan belajar anak.

\section{PENUTUP}

\section{Simpulan}

Dari hasil penelitian yang diuraikan pada bab IV maka dapat disimpulkan bahwa berdasarkan perhitungan korelasi antara pola asuh permisif orangtua (X) dengan hasil belajar (Y) terdapat pengaruh yang signifikan antara pola asuh permisif orangtua dengan kedisiplinan belajar anak di Lingkungan Pasar Baru Kelurahan Padang Masiang Barus. Yang menyebabkan adanya pengaruh yang berarti antara pola asuh permisif orangtua dengan kedisiplinan belajar anak yaitu, semakin tinggi pola asuh permisif orangtua maka semakin rendah kedisiplinan belajar anak di Lingkungan Pasar baru Kelurahan Padang Masiang Barus.

Berdasarkan hasil dari perhitungan determinasi, diketahui kedisiplinan belajar anak di Lingkungan Pasar Baru Kelurahan Padang Masiang Barus $31,24 \%$ dipengaruhi oleh pola asuh permisif orangtua sedangkan $68,76 \%$ dipengaruhi oleh faktor lain.

Saran
Berdasarkan kesimpulan di atas, penulis menyampaikan beberapa saran antara lain:

Kepada orangtua hendaknya menyadari bahwa keluarga merupakan lembaga pertama dalam kehidupan anak, tempat anak belajar dan menyatakan diri sebagai mahluk sosial. Keluarga memberikan dasar pembentukan tingkah laku, watak, moral dan pendidikan kepada anak. Pengalaman interaksi di dalam keluarga akan menentukan pula pola tingkah laku anak terhadap oranglain di dalam bermasyarakat. Walaupun anak telah dimasukkan kesekolah namun bukan berarti peran orangtua dalam mendidik anak hilang. Bahkan cara orangtua dalam menerapkan pola asuh untuk mendidik anaknya tersebut sangat berhubungan dengan kedisiplinan belajar anak. Dikarenakan terdapat pengaruh yang signifikann antara pola asuh permisif orangtua terhadap kedisiplinan belajar anak, maka disarankan kepada orangtua agar lebih meningkat pola asuh yang sesuai yang dapat meningkatkan kedisiplinan belajar anak.

Untuk para tenaga pendidik karena sekolah merupakan lembaga pendidikan setelah keluarga, hendaknya memperhatikan perkembangan anak 
dalam belajar yang dapat mempengaruhi

kedisiplinan anak dalam belajar.

Untuk para anak remaja $(13-15$ tahun) hendaknya anda menjadi anak remaja yang membanggakan orangtua, dan yang terpenting tingkatkan kedisiplinan dalam diri anda dan teruslah berusaha untuk mendapatkan prestasi dalam membangun bangsa

\section{DAFTAR PUSTAKA}

Ahmadi,Abu. 2009. Psikologi Sosial. Jakarta: Rineka Cipta.

Andri, Franc. 2014. Rahasia Otak dan Kecerdasan Anak.Yogyakarta: Teranova Books

Arikunto. 2002. Prosedur Penelitian. Jakarta: Rineka Cipta

Damsar. 2011. Pengantar Sosiologi Pendidikan. Jakarta: PT.Bumi Aksara

Daryo, A. 2007. Psikologi Perkembangan. Bandung: Rafika Aditama

Desmita. 2009. Psikolgi Perkembangan Peserta Didik. Jakarta: PT.Remaja

Gunarsa,S. 2010. Psikologi Keluarga. Jakarta: Gunung Mulia

Kasmadi. 2013. Panduan Modern Penelitian Kuantitatif. Bandung: Alfabeta

Kusdwiratri,S. 2011. Psikologi Keluarga. Bandung: Alumi
Lestari,Sri. 2012. Psikologi Keluarga. Yogyakarta: Kencana Prenada Media Group

Napitupulu, M. 2000. Wawasan Pendidikan Keluarga. Medan: Mitra Medan

Pasaribu,A. 2002. Pengantar Statistik. Jakarta: Ghalia Indonesia

Purwanto. 2009. Psikologi Pendidikan. Bandung: PT.Remaja Rosdakarya

Riduwan dan Sunarto. 2007. Pengantar Statistika. Bandung: Alvabeta

Sarwono,S. 2003. Psikologi Remaja (edisi revisi). Jakarta: Raja Grafindo Persada

Shochib,M. 2010. Pola Asuh Orangtua Dalam Membantu Anak Mengembangkan Disiplin Diri. Malang: Rineka Cipta

Slameto. 2011. Belajar Dan FaktorFaktor Yang Mempengaruhinya. Jakarta: Rineka Cipta

Sofyan,A. 2013. Pengembangan dan Model Pembelajaran dalam Kurikulum 2013 Surabaya: Prestasi Pustaka

Sudjana. 2002. Metode Statistik. Bandung: Tarsito

Sugiyono. 2013. Metode Penelitian Pendidikan. Bandung: Alfabeta

Sulistiyowati,S. 2001. Disiplin Belajar. Bandung: Pustaka Setia

Syatori,Toto. 2012.Metode Penelitian Kuantitatif. Bandung: CV.Pustaka 
Tu'u.Tulus. 2004. Peran Disiplin Pada Perilsku dan Prestasi Siswa. Jakarta: Grasindo

Umar,Asef. 2011.Terapan Quantum Learning untuk Keluarga Yogyakarta: Laksana
Usman,H. 2008. Pengantar Statistika. Jakarta: Bumi Aksara

Yusuf,S. 2004. Psikologi Perkembangan Anak dan Remaja. Bandung: Remaja Rosdakarya 